\title{
A Comparison of Writing Ability between Children with and without ADHD According to Length of Story
}

\author{
Sunhee Ko \\ Department of Speech-Language Pathology, Graduate School, Dankook University, Yongin, Korea
}

Correspondence: Sunhee Ko, PhD Department of Speech Language Pathology, Graduate School, Dankook University, 152 Jukjeon-ro, Suji-gu, Yongin 16890, Korea Tel: $+1-224-723-4528$

Fax: +1-847-941-8830

E-mail: sun7610@hanmail.com

Received: April 27, 2017

Revised: August 5, 2017

Accepted: August 18, 2017

\begin{abstract}
Objectives: For school-aged children, writing is an important means of communication and scholastic achievement; nevertheless, children with attention-deficit hyperactivity disorder (ADHD) have difficulty writing. Thus, this research studied how the length of story, which is one factor influencing writing, affected writing of children with ADHD. Methods: Sixteen children with ADHD and 16 normally-developing children in 3rd to 4th grade elementary school participated in the study. After listening to short and long stories they were asked to rewrite those stories and their writings were analyzed. Results: Children with $\mathrm{ADHD}$ wrote less in terms of quantity than the normally-developing children in the long story condition, but not in the short story condition. When analyzing the writing composition of both groups, the children with ADHD performed worse regardless of the length of the story. Syntactic complexity created no significant difference between the two groups, but both groups produced more complex syntax after the long story condition. In addition, both groups produced more sentences with syntactic errors after the long story condition and the children with ADHD made more sentences with syntactic errors in both conditions. Lastly, the children with ADHD produced more spelling errors in both conditions. Conclusion: When children with ADHD write a long story, they write less in terms of quantity than normally-developing children, which could explain why they write poorly. However, even when they can write equal quantity with normally-developing children, children with ADHD demonstrate poorer writing composition and produce more errors. These results are discussed in relationship to the characteristics of cognitive process.
\end{abstract}

Keywords: ADHD, Writing, Length of story
주의력결핍 과잉행동장애(attention-deficit hyperactivity disorder, $\mathrm{ADHD}$ )는 주의력, 과잉 행동 및 충동 행동이 부적절하게 발달 하여 일상생활에서 지속적으로 문제를 보이는 경우를 말한다(Barkley, 1997; Geffner, 2005). ADHD는 전두엽 및 기저핵의 기능장애 때문으로 보이며, 이 영역에서의 신경 전달 물질의 불균형이 이 장 애의 원인으로 받아들여지고 있다(Solanto, 2002). 또한, ADHD 아 동들에게서 흔히 나타나는 인지, 정서, 행동 문제들은 일반적으로 자기 통제, 반응 억제, 행동 조절 등을 아우르는 실행기능(executive function)의 결함으로 설명된다고 하였다(Barkley, 1997).

$\mathrm{ADHD}$ 아동들의 상당수는 일반적으로 정상적인 지능을 가지
고 있으나 학습에 현저한 어려움을 보이는 경우가 많으며, 사회·정 서적인 문제와함께 언어 문제를 동반하는 비율이 높다(Bruce, Thernlund, \& Nettelbladt, 2006; Oram, Fine, Okamoto, \& Tannock, 1999). 이들의 언어 특성을 살펴보면, 모호한 문장이나 비유적인 표현을 이해하는데 어려움이 있으며, 함축적인 의미 또는 이야기의 핵심 주제를 이해하는데도 어려움을 보인다. 또한 언어를 표현할 때 적 절한 단어를 선택하는데 어려움이 있고, 감정을 표현하는데 곤란 함을 겪으며, 효과적으로 자신의 생각을 전달하는데 미흡함이 있 다(DaParma, Geffner, \& Martin, 2011; Lim, 2010). ADHD 아동들 의 담화 능력에 초점을 둔 연구결과들을 보면, 이야기를 이해하고 
핵심 내용을 파악하는 것은 일반 아동들과 크게 차이를 보이지 않 았으나 전반적으로 내용이 부족하고, 인과적인 관계를 설명하는데 어려움이 있어 이야기의 응집성이 떨어지는 경향이 있으며, 잦은 오 류로 인해 이야기의 정확성이 낮았다(Lorch, Milich, \& Sanchez, 1998; Miranda, Soriano, \& Garcia, 2006; Purvis, \& Tannock, 1997; Tannock, Purvis, \& Schachar, 1993). 이같이 ADHD 아동들의 수 용-표현 언어 및 담화 능력을 고려한다면 이들이 보다 높은 수준의 통합 과정이 요구되는 글쓰기에서도 일반 아동들과 다른 양상을 보일수 있다.

글쓰기는 문자 언어를 통하여 자신의 감정, 생각, 경험 등을 표현 하고 의사소통하는 높은 수준의 지적 사고 과정으로(Klein, 1985), 다양한 요소들이 동시에 요구되기 때문에 듣기, 말하기, 읽기에 비 하여 상대적으로 고차원적인 기능이라 할 수 있다. 즉, 글쓰기는 쓰 고자 하는 내용을 구상하고, 적절한 단어를 선택하고, 올바른 철자 를 사용하고, 문법적으로 올바른 문장을 조직해야 하며, 더욱이 운 동 조절 능력이 포함되는 종합적인 과정이다(Ko \& Park, 2005). 학 령전기 아동들은 주로 구어를 통해 의사소통을 하지만 학령기에 접어들면서는 학교 교육을 통해 본격적으로 문어를 습득하게 된 다. 학령이 올라갈수록 글쓰기는 학습 영역에서의 중요한 수단이 되며, 성인이 되어서는 성공적인 삶을 살아가기 위한 필수적인 기능 이 된다(Yu \& Jeong, 2008). 일반적으로 고학년에 접어들면서 글쓰 기 부담이 크게 증가하여 $\mathrm{ADHD}$ 아동들이 글쓰기의 어려움에 노 출될 수 있기에(Ko, 2014) 본 연구에서는 초등학교 3-4학년 $\mathrm{ADHD}$ 아동을 대상으로 이들의 글쓰기 특성을 알아보고자 하였다.

$\mathrm{ADHD}$ 아동의 글쓰기 능력을 조사한 연구들은 언어 및 인지 능 력을 조사한 연구들에 비해 상대적으로 부족한 실정이며 최근에 들어서야 전문가들이 관심을 갖기 시작하였다. $\mathrm{ADHD}$ 아동들의 글쓰기 능력을 조사한 연구들에서 $\mathrm{ADHD}$ 아동들은 글쓰기 속도 면에서 일반 아동들과 차이가 없으며, 글로 써야 하는 주제나 글쓰 기 지식을 이해하고 있음에도 글의 조직력과 응집성에 있어서 일반 아동들에 비해 저조함을 보였다(Jacobson, \& Reid, 2010; Ko \& Hwang, 2013; Miranda et al., 2006; Noh \& Kim, 2013; Re, Caeran, \& Cornoldi, 2008; Re \& Cornoldi, 2010).

이 같이 $\mathrm{ADHD}$ 아동들이 글쓰기에 어려움을 보이는 이유를 다 음과 같이 정리할 수 있다. 첫째, $\mathrm{ADHD}$ 아동들은 글쓰기의 선수 기술인 언어 발달 측면에서 지연을 보이기 때문일 수 있다(Puranic \& Lonigan, 2012; Purvis \& Tannock, 1997). 실제로 연구들마다 수 치의 차이가 크기는 하나 ADHD 아동들의 $20 \%-60 \%$ 는 언어 문제 를 동반하는 것으로 보고되고 있다(Oram et al., 1999). 언어 능력이 글쓰기 능력의 기초가 되는 만큼 $\mathrm{ADHD}$ 아동들의 글쓰기 특성을
정확히 이해하기 위해서는 우선적으로 이들의 언어 지체 여부를 확인하는 것이 중요할 것이다. 둘째, $\mathrm{ADHD}$ 아동들은 궁극적인 목 표를 달성하기 위하여 문제를 해결하고 자신의 행동을 지속하고 조절하는 실행 기능에 결함을 보이는데(Barkley, 1997), 이 같은 인 지 기능의 결함으로 복잡한 처리 과정이 요구되는 글쓰기에서 어려 움을 보일 수 있다. 셋째, 작업기억 또한 $\mathrm{ADHD}$ 아동의 글쓰기에 영향을 미칠 수 있다. 작업 기억은 정보의 저장과 처리를 동시에 수 행하는 능력으로 정의되는데(Zoh, 1997), 글로 표현하고자 하는 정 보를 인출함과 동시에 내용을 조직하여 글로 써 내려가야 하는 과 정에서 개인의 작업기억 능력이 주요하게 작용할 수 있다(Peverly, 2006). 마지막으로, 글쓰기 전략 사용의 부재를 들 수 있다. 글쓰기 에 결함을 보이는 아동들은 자신의 생각들의 관계를 조직화하는 전략을 효율적으로 사용하지 못하며, 글을 산출하는데 급급하여 글의 통일성 및 완성도를 높이고자 자신의 글을 점검하거나 수정 하는데 한계를 보일 수 있다(Englert, Raphael, Anderson, Gregg, \& Anthony, 1989).

위에 제시한 원인들이 ADHD 아동들의 글쓰기에 영향을 미친 다면 글쓰기의 난이도나 부담 정도에 따라 $\mathrm{ADHD}$ 아동들의 글쓰 기 양상이 달라질 수도 있을 것이다. 따라서 본 연구에서는 $\mathrm{ADHD}$ 아동들이 언어 및 지적 능력에서 결함을 동반하지 않음에도 글쓰 기에 어려움을 보이는지, 글쓰기에 대한 부담을 달리하였을 때 그 조건에 따라 글쓰기 수행에 차이를 보이는지를 알아보았다. 이를 확인하기 위하여 길이가 각기 다른 두 개의 이야기를 $\mathrm{ADHD}$ 아동 들에게 들려주고 그 이야기를 쓰도록 하여 글의 산출양, 글의 구성 력, 구문 복잡성, 글의 정확성 전반에 걸쳐 분석하였다.

\section{연구방법}

\section{연구대상}

본 연구는 초등학교 3-4학년의 $\mathrm{ADHD}$ 아동 16 명과 정상 아동 16 명으로 총 32 명을 대상으로 하였다. $\mathrm{ADHD}$ 집단과 일반 아동 집 단은 3학년 남아 8 명, 3 학년 여아 1 명, 4 학년 남아 6 명, 4년 여아 1 명 으로 대상 아동들의 학년과 성비를 동일하게 통제하였다.

$\mathrm{ADHD}$ 아동들을 선별한 기준은 다음과 같다. (1) 서울과 경기 지역에 거주하며, (2) 소아정신과 전문의에게 $\mathrm{ADHD}$ 로 진단을 받 았으며, (3) K-WISC-III (Kwak, Park, \& Kim, 2001)를 실시한 결과 언어성 지능 및 동작성 지능이 85 이상으로 정상 범주에 속하였고, (4) 수용-표현어휘력검사(Receptive-Expressive Vocabulary Test, REVT; Kim, Hong, Kim, Jang, \& Lee, 2009)를 실시하여 그 결과가 -1 표준편차 이상으로 정상 범주에 속하였고, (5) 감각 영역에 문제 
Table 1. Participants' characteristics

\begin{tabular}{lcrc}
\hline & ADHD $(\mathrm{N}=16)$ & $\mathrm{TD}(\mathrm{N}=16)$ & $t$ \\
\hline K-WISK-III & $108.94(13.81)$ & $113.88(6.86)$ & 1.281 \\
REVT-Receptive (yr) & $12.19(1.38)$ & $12.06(1.29)$ & -.215 \\
REVT-Expressive (yr) & $12.13(1.59)$ & $12.13(1.20)$ & .000 \\
CAPRS & - & $7.38(1.26)$ & \\
\hline
\end{tabular}

Values are presented as mean (SD).

$\mathrm{ADHD}=$ children with attention-deficit hyperactivity disorder; $\mathrm{TD}$ = typically developing children; K-WISK-III = Korea-Wechsler Intelligence Scale for Children 3rd edition (Kwak, Park, \& Kim, 2001); REVT= Receptive Expressive Vocabulary Test (Kim, Hong, Kim, Jang, \& Lee, 2009); CAPRS= Conners Abbreviated Parent Rating Scale (Goyette, Conners, \& Ulrich, 1978).

가 없었으며, (6) 운동 기능의 장애를 동반하지 않는 아동들이었다. (7) 또한, 부모들이 검사일로부터 12 시간 전부터는 약물을 복용하 지 않는 것에 대해 동의를 하였다.

일반 아동의 선별 기준은 다음과 같다. (1) 서울과 경기 지역에 거 주하며, (2) 보호자가 정상 발달을 보인다고 보고하였고, (3) K-WISC$\mathrm{III}$ 의 언어성 지능과 동작성 지능이 모두 85 이상으로 정상 범주에 속하며, (4) REVT 결과 -1 표준편차 이상으로 정상 범주에 속하였 다. (5) 감각 영역에 문제가 없었으며, (6) 운동 기능 장애를 동반하 지 않는 아동이었다. (7) 코너스 단축형 부모 평정 척도(Conners Abbreviated Parent Rating Scale, CAPRS; Goyette, Conners, \& Ulrich, 1978)를 실시하여 10점 이하의 점수를 얻은 아동들이었다. 이 질문지는 총 10 문항으로 구성되어 있고 총점의 범위는 0-30점이 며 합산 총점이 16 점 이상일 경우 $\mathrm{ADHD}$ 를 의심하게 된다.

$\mathrm{ADHD}$ 아동들과 일반아동들의 지능, REVT-R, REVT-E, CAPRS 검사 결과는 Table 1 과 같다. $\mathrm{ADHD}$ 아동들과 일반 아동들 간에 지능, REVT-R, REVT-E 결과에 유의미한 차이가 있는지를 알아보 기 위해 $t$-검정을 실시한 결과 유의미한 차이는 나타나지 않았다.

\section{검사도구}

이야기 듣고 쓰기 과제는 이야기 길이를 달리한 두 개의 이야기 로 긴 이야기는 ‘돌부처와 장기 두는 총각’이고, 짧은 이야기는 ‘사 람을 구한 쥐'이다. Kim, Yoo, Hwang, Kim과 Koh (2010)이 사용한 읽기 이해 자료 중에 ‘돌부처와 장기 두는 총각'은 3학년 듣기 이해 능력을 평가하기 위해 사용된 이야기 자료이고, 사람을 구한 쥐'는 1 학년 듣기 이해를 평가하기 위해 사용된 이야기 자료로 두 이야기 모두 전문 이야기 작가에 의해 전래동화와 같은 형식으로 씨어져 이야기의 구조는 친숙할수 있으나 그 내용은 아동들이 지금까지 접 해본 적이 없는 낯선 이야기이다. 이 두 개의 이야기는 아동들에게 들려주기에 용이하게 어투와 일부 어휘가 수정되었다. 이와 같은 과정으로 수정.보완된 이야기 자료를 가지고 3학년 $\mathrm{ADHD}$ 아동 2
명과 3-4학년 정상 아동 3명에게 예비검사를 실시하여 과제 수행 시간, 어휘난이도, 이야기의 난이도, 쓰기 피로도를 점검하였다.

‘돌부처와 장기 두는 총각'과 '사람을 구한 쥐’는 이야기 구성이 적절한지, 이야기의 내용, 구문, 어휘가 3-4학년 아동들의 수준에 적합한지, 이야기의 길이가 잘 통제되었는지에 대하여 언어병리전 공 박사과정을 수료한 전문가 2 명에게 타당도를 검증 받았다. 최종 적으로 완성된 '돌부처와 장기 두는 총각(이하 긴 이야기)'은 총 19 문장, 141 어절, 4 개의 완벽한 에피소드를 포함하고 있으며 '사람을 구한 쥐(이하 짧은 이야기)'는 11문장, 62어절 2개의 완벽한 에피소 드를 포함하고 있다.

\section{연구절차}

$\mathrm{ADHD}$ 집단과 일반 아동 집단 각각에 대해 8 명은 긴 이야기를 먼저 들려주고 이야기를 다시 쓰도록 하였으며 나머지 8 명은 짧은 이야기를 먼저 들려주고 이야기를 쓰도록 하여 이야기의 제시 순서 가 결과에 영향을 미치는 것을 사전에 통제하였다.

본 실험을 위해 이야기를 들려줄 때 연구자가 아동에게 이야기 를 직접 읽어 주는 방식을 선택하였다. 이때 연구자는 읽기 속도와 목소리 크기를 적절하게 유지하여 아동들이 이야기를 듣고 이해하 기에 어려움이 없도록 하였으며, 아동이 흥미를 높이고자 이야기 상황에 적절하게 억양을 조절하면서 읽어 주었다. 다만 연구자가 이 야기를 읽어 줄 때는 모든 아동들에게 최대한 동일한 조건으로 읽 어줄수 있도록 사전에 반복 연습하였다.

아동들에게 본 이야기를 들려주기에 앞서 제목부터 들려주고 잠 시 후 본 이야기를 읽기 시작하였다. 연구자는 이야기를 읽어 주면 서 종종 아동과 눈을 맞추어 아동이 집중하여 듣는지를 확인하였 다. 하나의 이야기 과제를 마치고 나면 휴식을 하면서 다음 이야기 과제를 준비하였다. 아동들이 이야기를 쓸 때는 검사자가 곁에서 지켜보았으며 간혹 아동들이 쓰기를 멈추고 있을 때는 “그랬구나", “그래서?”, “그 다음에 어떻게 됐지?”라고 질문하여 쓰기를 지속할 수 있도록 하였다. 아동이 이야기를 쓰는 과정에서 연구자로부터 이야기 내용과 관련된 정보를 얻고자 “그 다음에 어떻게 됐죠?”, "OOO였나?”와 같은 질문을 할 때는 "OO가 생각해 보세요.", "생 각나는 대로 쓰면 되요.”와 같이 이야기 내용에 관련된 정보를 제 공하지 않는 범위에서 반응해 주었다. 각각의 이야기 쓰기검사가 끝나면 검사자는 아동이 쓴 글을 빠르게 훓어보면서 판독이 불가 능한 글자는 없는지, 이해가 어려운 부분은 없는지 확인하였고 필 요하다면 바로 아동에게 확인하는 과정을 거쳤다. 


\section{자료 분석}

아동들이 산출한 글을 분석하기 위해 Ko (2014)가 사용한 분석 기준을 사용하였고, 글의 산출량(총 산출 단어 수, 이야기 단위 회 상률), 이야기 구성력, 구문 복잡성(C-unit 당 평균 절의 수), 산출 정확성(비문율, 철자 오류율)에 대한 정의는 아래와 같다.

\section{글의 산출량}

아동이 산출한 글의 양을 수량화하기 위하여 각각의 이야기에 대한 총 산출 단어 수와 이야기 단위 회상률을 분석하였다. 총 산 출 단어 수는 들려준 이야기를 기준으로 하기보다는 단순히 아동 들이 산출한 글의 총량을 분석하는 것이고, 이야기 단위 회상률은 들려 준 이야기를 기준으로 하여 아동이 얼마나 많은 내용을 기억 하여 썼는지를 알아보는 것이다. '돌부처와 장기 두는 총각'은 32 개 의 이야기 단위로 '사람을 구한 쥐'는 15 개의 이야기 단위로 구성되 어 있어 이에 대한 회상률을 계산하였다.

\section{이야기 구성력}

아동이 들은 이야기를 근거로 하여 얼마나 글을 잘 조직하여 썼 는지를 알아보기 위하여 도입, 주제, 구성, 결말, 순서 5 가지의 영역 으로 나누어 이야기 구성력을 평가하였다. '도입'은 이야기의 배경 즉, 주인공의 이름이나 사건이 일어나는 시간을 분명히 언급하였는 지를 평가하며, '주제'는 결말과 관련되는 주인공의 주요 목표나 행 동이 명확하게 제시됐는지를 평가한다. '구성'은 에피소드를 구성 하는 모든 요소들을 적절히 언급함으로써 완전한 에피소드를 포 함하여 글을 썼는지를 평가한다. '결말'은 주인공이 문제를 해결하 고 마무리하는 내용을 포함하고 있는지를 평가하고, '순서'는 이야 기의 전개 순서가 적절한 지를 평가한다. 각각의 하위 영역마다 3점 척도인 $0,1,2$ 점으로 채점하고 이들 점수를 모두 합산하여 최종적 으로 각아동의 이야기 구성력 최종 점수를 산출하였다.

\section{구문 복잡성}

아동들이 산출한 글의 구문 복잡성을 알아보기 위하여 아동이 쓴 글을 C-unit으로 구분하고 절의 수를 분석한 후, 전체 절의 수를 C-unit 수로 나누어 최종적으로 C-unit 당 평균 절의 수를 산출하 였다.

\section{산출 정확성}

아동이 쓴 글의 오류를 분석하기 위하여 비문율과 철자 오류율 을 계산하였다. 첫째, 비문은 문법적인 오류를 포함하고 있는 Cunit으로 정의된다. 비문은 (1) 문장 성분의 호응 오류, (2) 문장 성
분 생략 오류, (3) 조사 사용의 오류, (4) 어미 사용의 오류, (5) 중복 표현으로 인한 오류, (6) 지나치게 긴 문장으로 인한 오류, (7) 시제 표현의 오류, (8) 문장 미완성으로 분석하였다. 비문율은 비문이 포 함된 C-unit 수를 전체 산출 C-unit의 수로 나눈 다음 100 을 곱하 여 산출하였다. 둘째, 철자 오류는 한글 맞춤법이 틀린 경우이고, 철자 오류율은 맞춤법 오류가 있는 단어의 수를 전체 산출 단어 수 로 나눈 후 100 을 곱하여 산출하였다.

\section{신뢰도}

자료 분석의 신뢰도를 측정하고자 일반 아동과 $\mathrm{ADHD}$ 아동 각 각 4 명씩, 총 8 명의 글 자료를 언어병리박사과정을 수료하고 1 급 언 어치료사 자격증이 있는 언어치료사 1 명에게 분석을 의뢰하여 그 결과가 연구자의 분석과 얼마나 일치하는지를 알아보았다. 그 결 과, 총 산출 단어 수는 $99 \%$, 이야기 단위 회상률은 $90 \%$, 이야기 구 성력에 대한 일치율은 91\%, C-unit 당 평균 절의 수 $98 \%$, 비문율은 $97 \%$, 철자 오류율 $98 \%$ 의 일치도를 보였다. 연구자와 신뢰도 평가자 간에 불일치 하는 내용은 함께 논의한 후 분석에 적용하였다.

\section{자료처리}

$\mathrm{ADHD}$ 아동과 일반 아동들 간에 길이가 다른 두 개의 이야기 각 각에 대한 총 단어 산출수가 차이가 있는지를 알아보고자 $t$-검정 을 실시하였고, $\mathrm{ADHD}$ 아동들과 일반 아동들에게 들려주는 이야 기의 길이에 따라 집단 간 글쓰기 수행(이야기 단위 회상률, 이야기 구성력, 구문 복잡성, 비문율, 철자 오류율)에 차이가 있는지를 알 아보고자 이야기 길이 $(2) \times$ 집단(2) 반복측정 이원분산분석를 실시 하였다. 통계적인 처리를 위해 SPSS Windows 18.0 을 사용하였다.

\section{연구결과}

아동들에게 길이가 각기 다른 두 개의 이야기를 들려주고 이야 기를 다시 쓰도록 한 다음 아동들이 쓴 글을 분석하였다. 글의 산 출양을 측정하기 위해서 총 산출 단어 수와 이야기 단위 회상률을, 글의 질적인 측면을 측정하기 위하여 이야기 구성력을, 구문의 복 잡성 평가하기 위하여 C-unit 당 평균 절의 수를, 마지막으로 글의 정확도를 측정하기 위하여 비문율, 철자 오류율을 분석하였다.

\section{글의 산출량}

\section{총 산출 단어 수}

아동들에게 들려준 이야기를 기반으로 하여 아동들이 산출한 글의 총량을 측정하고자 총 산출 단어 수를 계산하였고, 그 기술통 
Table 2. Total number of words

\begin{tabular}{lccc}
\hline & $\operatorname{ADHD}(\mathrm{N}=16)$ & $\mathrm{TD}(\mathrm{N}=16)$ & $t$ \\
\hline Long story & $96.00(20.32)$ & $122.31(24.07)$ & $-3.341^{*}$ \\
Short story & $66.31(8.41)$ & $70.31(15.51)$ & -.907
\end{tabular}

Values are presented as mean (SD).

$\mathrm{ADHD}=$ children with attention-deficit hyperactivity disorder; $\mathrm{TD}=$ typically developing children.

${ }^{*} p<.05$.

Table 3. Rate of story unit depending on the story length

\begin{tabular}{lll}
\hline & $\operatorname{ADHD}(\mathrm{N}=16)$ & \multicolumn{1}{c}{$\mathrm{TD}(\mathrm{N}=16)$} \\
\hline Long story & $47.46(11.54)$ & $60.94(8.54)$ \\
Short story & $68.75(13.05)$ & $70.42(12.40)$ \\
\hline
\end{tabular}

Values are presented as mean (SD).

$\mathrm{ADHD}=$ children with attention-deficit hyperactivity disorder; $T \mathrm{D}=$ typically developing children.

계 결과는 Table 2와같다.

길이가 다른 각각의 이야기를 듣고 두 집단이 산출한 글의 양에 있어 집단 간 차이가 있는지를 알아보고자 독립표본 $t$-검정을 실시 하였다. 그 결과 길이가 긴 이야기를 듣고 산출한 총 산출 단어 수 는 $\mathrm{ADHD}$ 아동들이 일반 아동들과 비교하여 유의미하게 적었으 나 짧은 글을 듣고 총 산출 단어 수는 $\mathrm{ADHD}$ 아동과 일반 아동들 간에 유의미한차이를 보이지 않았다.

\section{이야기 단위 회상률}

아동들에게 들려준 이야기를 기반으로 하여 아동들이 회상한 이야기 단위 회상률을 분석하였고, 그 기술통계 결과는 Table 3 과 같다.

두 집단 간에 이야기의 길이가 다른 두 조건에서 산출된 이야기 단위 회상률의 차이가 있는지를 알아보고자 이원분산분석을 실시 하였다. 그 결과에 따르면, 집단 간 주효과 $\left(F_{(1,30)}=6.340, p<.05\right)$, 이 야기 길이에 대한 주효과 $\left(F_{(2,60)}=3785.33, p<.001\right)$, 이야기 길이와 집단에 따른 상호작용 효과 $\left(F_{(2,60)}=557.90, p<.05\right)$ 모두 유의미한 것으로 나타났다. $\mathrm{ADHD}$ 아동들은 일반 아동들에 비해 이야기 단 위 회상률이 유의미하게 적었으며, 두 집단 모두 짧은 이야기를 듣 고 회상할 때 보다 긴 이야기를 듣고 회상할 때 이야기 단위 회상률 이 저조하였다. 그러나 ADHD 아동들이 일반 아동들과 달리 들려 준 이야기 길이에 따라 이야기 단위 회상률에 더 큰 영향을 받는 것 으로 나타났다.

\section{이야기 구성력}

이야기 길이가 다른 두 가지의 이야기를 듣고 아동들이 산출한
Table 4. Story composition depending on the story length

\begin{tabular}{lcc}
\hline & $\mathrm{ADHD}(\mathrm{N}=16)$ & $\mathrm{TD}(\mathrm{N}=16)$ \\
\hline Long story & $7.13(1.66)$ & $8.56(.83)$ \\
Short story & $7.31(1.29)$ & $8.55(1.41)$ \\
\hline
\end{tabular}

Values are presented as mean (SD).

$\mathrm{ADHD}=$ children with attention-deficit hyperactivity disorder; $T \mathrm{D}=$ typically developing children.

Table 5. Mean number of clause per C-unit depending on the story length

\begin{tabular}{lcc}
\hline & $\mathrm{ADHD}(\mathrm{N}=16)$ & $\mathrm{TD}(\mathrm{N}=16)$ \\
\hline Long story & $2.19(.49)$ & $2.05(.31)$ \\
Short story & $1.96(.29)$ & $1.94(.34)$ \\
\hline
\end{tabular}

Values are presented as mean (SD).

$\mathrm{ADHD}=$ children with attention-deficit hyperactivity disorder; $T \mathrm{D}=$ typically developing children.

글에 대한 이야기 구성력을 평가하였고, 그 결과는 Table 4와같다. 이야기 길이에 따라 이야기 구성력에 차이가 있는지를 알아보고 자 이원분산분석을 실시하였다. 그 결과를 보면, 집단 간 주효과가 유의미하였지만 $\left(F_{(1,30)}=2304.28 p<.001\right)$ 이야기 길이에 따른 주효 과와 이야기 길이와 집단 간 상호작용 효과에서는 유의미하지 않 았다. 이는 $\mathrm{ADHD}$ 아동들은 들려준 이야기 길이와 상관없이 전반 적으로 일반 아동들에 비해 이야기 구성하는데 어려움을 보이는 것을 알수 있다.

\section{구문 복잡성}

이야기 길이가 다른 두 조건의 이야기를 듣고 아동들이 쓴 글의 구문 복잡성을 알아보고자 C-unit 당 포함된 평균 절의 수를 분석 하였다. 이에 대한 기술통계 결과는 Table 5와같다.

C-unit 당 평균 절의 수가 이야기의 길이가 다른 두 이야기 조건에 따라 집단 간 차이가 있는지를 알아보자 이원분산분석을 실시하였 다. 그 결과, 이야기 길이에 따른 주효과는 유의미하였으나 $\left(F_{(1,30)}=\right.$ $4.579 p<.05)$, 집단 간 주효과와 이야기 길이와 집단 간 상화작용 효과는 유의미하지 않았다. 이 같은 결과를 보면 $\mathrm{ADHD}$ 아동들과 일반 아동들 모두 이야기를 쓸 때 유사한 구문 복잡성을 산출하였 으나 두 집단 모두 짧은 이야기 조건에서보다 긴 이야기 조건에서 구문의 복잡성이 증가하였음을 알 수 있다.

\section{산출 정확성}

들려주는 이야기의 길이가 각기 다른 두 이야기를 듣고 아동들 이 산출한 글의 정확성을 측정하고자 비문율, 철자 오류율을 분석 하였다. 
Table 6. Percentage of ungrammatical sentences depending on the story length

\begin{tabular}{lcl}
\hline & ADHD (N=16) & TD (N=16) \\
\hline Long story & $22.17(14.37)$ & $9.25(3.64)$ \\
Short story & $11.40(13.44)$ & $2.91(4.53)$ \\
\hline
\end{tabular}

Values are presented as mean (SD).

$\mathrm{ADHD}=$ children with attention-deficit hyperactivity disorder; $T D=$ typically developing children.

\section{비문율}

$\mathrm{ADHD}$ 아동들과 일반 아동들이 산출한 글의 비문율을 분석한 기술통계 결과는 Table 6과 같다.

이야기 길이가 다른 두 조건에서 집단 간 비문율에 차이가 있는 지를 알아보고자 이원분산분석을 실시하였다. 그 결과를 보면, 집 단 간 주효과가 유의미하였고 $\left(F_{(1,30)}=49.279, p<.001\right)$, 길이에 따른 주효과 역시 유의미하였다 $\left(F_{(1,30)}=9.206, p<.001\right)$. 반면에 집단과 이야기 길이에 따른 상호작용 효과는 유의미하지 않았다. 즉, $\mathrm{ADHD}$ 아동들은 일반 아동들에 비해 전반적으로 비문을 산출하는 비율 이 높았으나 $\mathrm{ADHD}$ 아동들뿐 아니라 일반 아동들도 들려주는 이 야기의 길이가 길어질수록 비문율이 증가했음을 알 수 있다.

\section{철자 오류율}

$\mathrm{ADHD}$ 아동들과 일반 아동들이 쓴 글에 나타난 철자 오류율을 분석하였고, 그 기술통계 결과를 보면 Table 7과 같다.

들려준 이야기 길이에 따라 철자 오류율에 차이가 있는지를 알 아보기 위해 이원분산분석을 실시하였다. 그 결과, 집단 간 주효과 는 유의미하였으나 $\left(F_{(1,30)}=31.742, p<.0001\right)$, 이야기 길이에 따른 주효과와 이야기 길이와 집단 간 상호작용 효과는 유의미하지 않 았다. 이 같은 결과로 볼 때, $\mathrm{ADHD}$ 아동들은 들려준 이야기 길이 와 상관없이 일반 아동들에 비해 더 많은 철자 오류를 보이는 것을 알수 있다.

\section{논의 및 결론}

본 연구는 3-4학년의 $\mathrm{ADHD}$ 아동들에게 길이가 각기 다른 두 개의 이야기를 들려준 후 들은 이야기를 다시 쓰도록 하여 이야기 길이가 아동들의 글쓰기에 어떠한 영향을 미치는지에 대해 다양한 측면에서 살펴 보았으며 다음과 같이 논의하였다.

첫째, 아동들이 쓴 글의 양을 분석하고자 총 산출 단어 수와 이 야기 단위 회상률을 분석하였다. 실제로 $\mathrm{ADHD}$ 아동들은 이야기 가 짧았을 때는 글을 쓰는 양이 일반 아동들과 차이가 없었으나 이
Table 7. Rate of spelling error depending on the story length

\begin{tabular}{lcc}
\hline & ADHD $(\mathrm{N}=16)$ & $\mathrm{TD}(\mathrm{N}=16)$ \\
\hline Long story & $4.97(5.41)$ & $1.51(1.47)$ \\
Short story & $4.82(3.95)$ & $1.70(1.97)$
\end{tabular}

Values are presented as mean (SD).

$\mathrm{ADHD}=$ children with attention-deficit hyperactivity disorder; $\mathrm{TD}=$ typically developing children.

야기가 길었을 때는 일반 아동들보다 적은 양의 글을 산출하였다. 구체적으로 이야기 단위 회상률을 살펴보면, $\mathrm{ADHD}$ 아동들이 일 반 아동들에 비해 적은 비율의 이야기 단위 수를 회상하였으며, 짧 은 이야기에 비해 긴 이야기에서 기억하는 이야기 단위 수가 적은 것으로 나타났다. 일반 아동들 역시 비슷한 경향을 보였으나 $\mathrm{ADHD}$ 아동들이 유독 이야기의 길이에 영향을 받아 긴 이야기 조건에서 현저히 저조한 이야기 단위 수를 회상하였다. $\mathrm{ADHD}$ 아동들이 긴 이야기를 쓸 때 적은 양의 글을 산출한 것은 이야기를 듣는 과정에 서 정보를 저장하지 못하였기 때문일 수 있겠으나, 다른 한편으로 는 이야기를 들으면서 이해를 성공적으로 했다 하더라도 이를 재조 직하여 글로 써야 하는 복잡한 처리 과정에서 일부의 내용을 누락 시켰을 수 있다. 많은 연구들에서 $\mathrm{ADHD}$ 아동들이 작업기억의 결 함을 보이는 것으로 보고 있는데 글쓰기에서도 이 같은 결함이 영 향을 미쳤을 수 있다(Barkley, 2003; Jacobson et al., 2011; Martinussen, Hayden, Hogg-Johnson, \& Tannock, 2005; Martinussen \& Major, 2011; Martinussen \& Tannock, 2006; Re \& Cornordi, 2010).

둘째, 아동들이 산출한 글이 주요 내용을 포함하여 적절하게 조 직되었는지에 대한 전반적인 구성력을 분석하였다. 그 결과, $\mathrm{ADHD}$ 아동들은 긴 이야기에서뿐만 아니라짧은 이야기에서조차 일반 아 동들에 비해 낮은 점수를 얻었다. 글을 쓰는 양이 많다고 해서 반드 시 그 글이 잘 쓰여진 글이라고 확언할 수는 없겠으나 완성도가 높 은 글을 쓰기 위해서는 양적인 측면에서의 충족이 우선되어야 한 다. 그런 면에서 $\mathrm{ADHD}$ 아동들이 긴 이야기를 글로 쓸 때 전체 산 출한 글의 양이나 이야기 단위 회상 수가 일반 아동들보다 적었기 때문에 일반 아동들에 비해 글의 완성도가 떨어졌을 수 있다. 그러 나짧은 이야기를 글로 쓸 때는 $\mathrm{ADHD}$ 아동들이 산출한 글의 양적 인 측면에서 일반 아동들에 비해 부족함이 없었음에도 글 구성력 에서 역시 낮은 점수를 얻었다. 이는 $\mathrm{ADHD}$ 아동들의 경우 전달하 는 내용의 양에 비해 독자에게 전달해야 하는 주요 내용을 포함하 여 전달하거나 그 내용을 효율적으로 전달하기 위해 글을 재조직 하고 구성하는데 어려움이 있다는 것을 의미한다. 이야기의 친숙 성을 조절하거나 그림 및 언어적인 단서를 단계적으로 조절함으로 써 $\mathrm{ADHD}$ 아동들이 글쓰기에 어려움을 보이는 원인을 알아보고 
자 했던 선행연구들에서 글쓰기 부담을 조절하여도 $\mathrm{ADHD}$ 아동 들이 여전히 글의 조직하고 구성하는 데 어려움을 보였다는 결과 들과 맥을 같이 한다(Ko, 2014; Re, Pedron, \& Cornoldi, 2007). 결 국 글쓰기는 자신이 가지고 있는 지식을 기반으로 하되 글의 완성 도를 높이기 위하여 내용을 효율적으로 조직하는 전략을 사용하 여야 하는데(Choi, 2005), 이 부분에서 ADHD 아동들이 일반 아 동들에 비해 어려움을 겪는 것으로 해석된다.

셋째, 아동들이 산출한 글의 구문 복잡성을 평가하기 위하여 Cunit 당 평균 절의 수를 분석하였다. 그 결과, $\mathrm{ADHD}$ 아동들과 일 반 아동들 간에 구문 복잡성에 있어서 유의미한 차이가 나타나지 않았고, $\mathrm{ADHD}$ 아동들과 일반 아동들 모두 긴 이야기를 쓸 때 구 문 복잡성이 증가하였다. 이 같은 결과는 Ko (2014)의 연구에서 친 숙도를 달리한 두 개의 이야기를 들려주고 일반 아동들과 $\mathrm{ADHD}$ 아동들의 글쓰기를 평가하였는데 두 집단 모두 친숙한 이야기보다 비친숙한 이야기를 글로 쓸 때 구문 복잡성이 증가하였다는 결과 와 일치한다. 결국 친숙도가 낮거나 전달해야 하는 정보의 양이 많 을 경우와 같이 글쓰기 부담이 증가하는 상황에서는 내용과 문장 이 덜 조직된 상태로 글을 쓰게 되면서 다소 복잡한 구문을 산출할 가능성이 있는 반면 정보를 기억하거나 인출하는 데 부담이 적은 상황에서 글을 쓸 때는 의도하는 내용을 문장으로 조직하는 것이 상대적으로 수월하여 구문을 조직할 때도 보다 명료하고 간결하게 산출하는 경향을 보였을 수 있다. 구문 복잡성 결과를 비문율 결과 와 연결 지어 생각해 보면 이같은 설명에 무게를 실을 수 있다. $\mathrm{ADHD}$ 아동들과 일반 아동들 모두 짧은 이야기를 글로 쓸 때보다 긴 이야 기를 글로 쓸 때 비문율이 증가하였다. 이 같은 결과는 Ko (2014)의 연구에서 친숙도가 낮아 정보를 기억해야 하는 부담이 증가하였을 경우 친숙도가 낮은 경우에 비해 $\mathrm{ADHD}$ 아동과 일반 아동 모두 구 문 복잡성이 증가하고 비문율이 높았다는 결과와 일치한다. 결국, 글을 쓸 때 특정한 원인으로 글쓰기의 부담이 증가하면 내용을 명 료하고 간략한 문장으로 조직하는데 다소 어려움이 생겨 산출하 는 문장의 길이가 길어지는 경향을 보이며 그 과정에서 구문 오류 의 빈도도 함께 높아지는 것이다.

마지막으로, 아동들이 쓴 글의 정확도를 평가하기 위해 비문율, 철자 오류율을 분석하였다. ADHD 아동들은 일반 아동들에 비해 전반적으로 더 많은 비문을 산출하는 경향을 보였으며, 앞서 일부 언급한 바와 같이 $\mathrm{ADHD}$ 아동들과 일반 아동들 모두 긴 이야기를 글로 쓸 때 높은 빈도의 비문을 산출하였다. 여러 선행연구들에서 도 일관되게 $\mathrm{ADHD}$ 아동들이 일반 아동들보다 빈번한 구문 오류 를 산출하는 것으로 보고하였다(Miranda et al., 2006; Re et al., 2007, 2008; Re \& Cornoldi, 2010). 이야기를 글로 쓰기 위해서는 무엇을
글로 쓸 것인지를 구상하고 조직해야 하며 실시간으로 점검하여 문장 내의 오류를 최소화하여야 하는데 $\mathrm{ADHD}$ 아동들의 인지적 인 특성으로 인해 쉽지 않았을 수 있다(Barkley, 1997; Holmes et al., 2010; Miranda et al., 2006). 또한 철자 오류율을 살펴보면, ADHD 아동들은 이야기 길이와 상관없이 일반 아동들에 비해 더 잦은 오 류를 산출하여 $\mathrm{ADHD}$ 아동들이 철자 오류를 빈번히 보이는 것은 조건에 영향을 받기보다는 발달적으로 미성숙한 상태라고 결론지 을 수 있다. 일반적으로 저학년 아동들에게서 철자 오류가 빈번히 나타나다가 고학년으로 갈수록 특히 4 학년이 되면서 철자 오류가 급격히 감소하는 경향을 보이는데(Ahn \& Kim, 2010), ADHD 아 동들의 경우는 고학년이 되어서도 철자 쓰기의 어려움이 지속되고 있음을 알수 있다.

본 연구의 결과를 종합하여 보면, 글을 쓸 때의 부담이 증가하면 $\mathrm{ADHD}$ 아동들은 일차적으로 주요 정보를 인출하는데 어려움을 보였으며, 글쓰기 부담이 낮아져 정보를 인출하는데 어려움이 없는 상황에서도 제한적인 글 구성력을 보였다. 또한 $\mathrm{ADHD}$ 아동들은 글을 쓸 때 높은 빈도로 구문적인 오류와철자 오류를 보였다. $\mathrm{ADHD}$ 아동들이 글쓰기의 어려움을 보이는 것은 실행기능 및 작업기억의 결함에 기인한 것일 수 있기에 이 같은 인지 기능의 한계를 최대한 극복하기 위해서 무엇보다도 아동들에게 글쓰기에 대한 구체적인 전략, 즉 글의 종류나 목적에 따라 내용을 조직하거나 점검할 수 하 는 등의 전략을 습득할 수 있도록 중재할 필요가 있을 것이다.

그동안 $\mathrm{ADHD}$ 아동들의 글쓰기 특성을 알아보기 위하여 여러 연구들에서 주로 주제를 제시하고 아동들이 자유롭게 글을 쓰도 록 하는 방법을 사용하였는데(Jacobson \& Reid, 2010; Miranda et al., 2006; Re \& Cornoldi, 2010; Re et al., 2008) 이는 자연스러운 글 쓰기를 유도할 수 있다는 장점이 있으나 주제와 관련된 배경지식을 통제하는데 한계가 있을 수 있다. 반면에 본 연구에서 그 한계를 극 복함과 동시에 글을 쓸 때의 조건을 통제함으로써 $\mathrm{ADHD}$ 아동들 의 글쓰기의 특성과 그 원인을 설명하고자 했다는 점에서 의의가 있다. 마지막으로, 본 연구결과들을 바탕으로 $\mathrm{ADHD}$ 아동들의 성 공적인 글쓰기를 유도하기 위하여 다양한 중재 전략들이 연구·개 발될 필요가 있음을 제안한다.

\section{REFERENCES}

Ahn, E., \& Kim, J. (2010). The expository writing abilities of school-aged children. Korean Journal of Communication Disorders, 15, 321-336.

Barkley, R. A. (1997). Behavioral inhibition, sustained attention, and executive function: constructing a unifying theory of ADHD. Psychological Bul- 
letin, 121, 65-94.

Barkley, R. A. (2003). Issues in the diagnosis of attention-deficit/hyperactivity disorder in children. Brain and Development, 25, 77-83.

Bruce, B., Thernlund, G., \& Nettelbladt, U. (2006). ADHD and language impairment: a study of the parent questionnaire FTF (five to fifteen). European Child \& Adolescent Psychiatry, 15, 52-60.

Choi, J. I. (2005). An action research on teaching-learning in strategy centered writing for primary students (Master's thesis). Duksung Woman's University, Seoul, Korea.

DaParma, A., Geffner, D., \& Martin, N. (2011). Prevalence and nature of language impairment in children with attention deficit/hyperactivity disorder. Contemporary Issues in Communication Science and Disorders, 38, 119-125.

Englert, C., Raphael, T., Anderson, L., Gregg, S., \& Anthony, H. (1989). Exposing: reading, writing, and the meta-cognitive knowledge of learning disabled students. Learning Disabilities Research, 5, 5-24.

Geffner, D. (2005). Attention deficit-hyperactivity disorder: what professionals need to know. Eau Claire, WI: Thinking Publications.

Goyette, C. H., Conners, C. K., \& Ulrich, R. F. (1978). Normative data on revised Conners parent and teacher rating scales. Journal of Abnormal Child Psychology, 6, 221-236.

Holmes, J., Gathercole, S. E., Place, M., Alloway, T. P., Elliott, J. G., \& Hilton, K. A. (2010). The diagnostic utility of executive function assessments in the identification of ADHD in children. Child and Adolescent Mental Health, $15,37-43$.

Jacobson, L. A., Ryan, M., Martin, R. B., Ewen, J., Mostofsky, S. H., Denckla, M. B., \& Mahone, E. M. (2011). Working memory influences processing speed and reading fluency in ADHD. Child Neuropsychology, 17, 209-224.

Jacobson, L. T., \& Reid, R. (2010). Improving the persuasive essay writing of high school students with ADHD. Exceptional Children, 76, 157-174.

Kim, A. H., Yoo, H. S., Hwang, M., Kim, U. J., \& Koh, S. R. (2010). Prediction of reading comprehension in elementary school students. Korean Journal of Communication Disorders, 15, 357-380.

Kim, Y. T., Hong, G. H., Kim, K. H., Jang, J. S., \& Lee, J. Y. (2009). Receptive \& expressive vocabulary test (REVT). Seoul: Seoul Community Rehabilitation Center.

Klein, M. (1985). The development of writing in children: pre-K through 8. Englewood Cliffs, NJ: Houghton Mifflin.

Ko, H., \& Park, H. (2005). The effects of the instruction with story grammar and self-evaluation strategy on written expression ability in intermediate graders with writing disabilities. Korean Journal of Special Education, 40,
211-303.

Ko, S. (2014). Narrative writing skills of children with and without ADHD. Communication Sciences and Disorders, 19, 9-20.

Ko, S., \& Hwang, M. (2013). Comparing writing ability between ADHD and normal children. Korean Journal of Learning Disabilities, 10, 9-20.

Kwak, K. C., Park, H. W., \& Kim, C. T. (2001). Korean Wechsler Intelligence Scale for Children-III (K-WISC-III). Seoul: Seoul Special Education Publishing.

Lim, J. (2010). The comprehension of figurative meaning in ADHD children with and without language impairment. Korean Journal of Communication Disorders, 15, 307-320.

Lorch, E. P., Milich, R., \& Sanchez, R. P. (1998). Story comprehension in children with ADHD. Clinical Child and Family Psychology Review, 1, 163-178.

Martinussen, R., \& Major, A. (2011). Working memory weaknesses in students with ADHD: implications for instruction. Theory Into Practice, 50, 68-75.

Martinussen, R., \& Tannock, R. (2006). Working memory impairments in children with attention-deficit hyperactivity disorder with and without comorbid language learning disorders. Journal of Clinical and Experimental Neuropsychology, 28, 1073-1094.

Martinussen, R., Hayden, J., Hogg-Johnson, S., \& Tannock, R. (2005). A meta-analysis of working memory impairments in children with attention deficit/hyperactivity disorder. Journal of the American Academy of Child and Adolescent Psychiatry, 44, 377-384.

Miranda, A., Soriano, M., \& Garcia, R. (2006). Reading comprehension and written composition problems of children with ADHD: discussion of research and methodological considerations. Advances in Learning and Behavioral Disabilities, 19, 237- 256.

Noh, S. L., \& Kim, E. K. (2013). Written expression characteristics of elementary students with ADHD. Korean Journal of Special Education, 48, 207228.

Oram, J., Fine, J., Okamoto, C., \& Tannock, R. (1999). Assessing the language of children with ADHD. American Journal of Speech-Language Pathology, $8,72-80$

Perverly, S. T. (2006). The importance of handwriting speed in adult writing. Developmental Neuropsychology, 29, 197-216.

Puranik, C. S., \& Lonigan, C. J. (2012). Early writing deficits in preschoolers with oral language difficulties. Journal of Learning Disabilities, 45, 179-190.

Purvis, K. L., \& Tannock, R. (1997). Language abilities in children with ADHD, reading disabilities, and normal controls. Journal of Abnormal Child Psy- 
Sunhee Ko • Comparing Writing Ability between ADHD and Normal Children

chology, 25, 133-144.

Re, A. M., \& Cornoldi, C. (2010). ADHD expressive writing difficulties of ADHD: when good declarative knowledge is not sufficient. European Journal of Psychological Education, 25(3), 315-323.

Re, A. M., Caeran M., \& Cornoldi, C. (2008). Improving expressive writing skills of children rated for ADHD symptoms. Journal of Learning Disabilities, 41, 535-544.

Re, A. M., Pedron, M., \& Cornoldi, C. (2007). Expressive writing difficulties in children described as exhibiting ADHD symptoms. Journal of Learning Disabilities, 40, 244-255.
Solanto, M. V. (2002). Dopamine dysfunction in ADHD: integrating clinical and basic neuroscience research. Behavioral Brain Research, 130, 65-71.

Tannock, R., Purvis, K. L., \& Schachar, R. J. (1993). Narrative abilities in children with ADHD and normal peers. Journal of Abnormal Child Psychology, 21, 103-117.

Yu, G., \& Jeong, E. (2008). Writing characteristics of school-aged children with specific language impairment. Korean Journal of Communication Disorders, 13, 63-85.

Zoh, M. H. (1997). Working memory and individual differences in reading comprehension. Korean Journal of Psychology: General, 16, 18-39. 


\section{국문초록}

\section{이야기의 길이에 따른 ADHD 아동과 일반 아동의 글쓰기 특성 비교} 고선희

단국대학교 대학원 언어병리학과

배경 및 목적: 학령기 아동들에게 글쓰기는 의사소통 및 과업 성취를 위한 필수적인 수단임에도 $\mathrm{ADHD}$ 아동들이 이에 어려움을 겪 는 것으로 보고되고 있다. 본 연구에서는 글쓰기에 영향을 미치는 요인 중 하나인 이야기의 길이가 $\mathrm{ADHD}$ 아동들의 글쓰기 전반에 어 떠한 영향을 미치는 지에 대해 알아보았다. 방법: 초등학교 3-4학년의 $\mathrm{ADHD}$ 아동과 일반 아동 각각 16 명씩, 총 32명을 대상으로 하였 고, 긴 이야기와 짧은 이야기를 들려주고 글을 쓰도록 하여 $\mathrm{ADHD}$ 아동들과 일반 아동들 간의 글쓰기 수행을 비교하였다. 결과: $\mathrm{ADHD}$ 아동들은 일반 아동들에 비해 긴 이야기 조건에서 일반 아동들보다 유의미하게 적은 양의 글을 산출하였으며, $\mathrm{ADHD}$ 아동들 은 들려준 이야기의 길이와상관없이 일반 아동들보다 이야기 구성력에서 저조한 수행을 보였다. 구문 복잡성에 있어서 두 집단 간에 유 의미한 차이를 보이지는 않았으나 두 집단 모두 긴 이야기 조건에서 보다 복잡한 구문을 산출하였다. 또한 비문율을 보면 두 집단 모두 긴 이야기 조건에서 더 많은 비문을 산출하는 경향을 보였으나, $\mathrm{ADHD}$ 아동들이 두 조건 모두에서 일반 아동들보다 높은 빈도의 비문 을 산출하였다. 철자 오류율에 있어서는 이야기 조건과 상관없이 $\mathrm{ADHD}$ 아동들이 일반 아동들에 비해 유의미하게 높은 빈도의 오류 를 보였다. 논의 및 결론: 글로 써야 하는 내용이 많을 때는 $\mathrm{ADHD}$ 아동들이 일반 아동들에 비해 적은 양의 글을 산출하는 것이 전반 적인 글의 질이 떨어지는 요인일 수 있겠으나, 짧은 이야기를 쓸 때 $\mathrm{ADHD}$ 아동들이 산출한 글의 양이 적지 않음에도 그 내용을 조직하 고 구성하는데 여전히 어려움을 보였다. 이같은 결과를 $\mathrm{ADHD}$ 아동들의 인지 처리 특성과 연결지어 논의하였다.

핵심어: 쓰기, $\mathrm{ADHD}$, 이야기 길이

\section{참고문헌}

고선희(2014). 이야기 듣고 다시 쓰기를 통해 나타난 ADHD 아동과 일반 아동의 글쓰기 특성 비교. 언어청각장애연구, 19, 9-20.

고선희, 황민아(2013). ADHD 아동과 일반 아동의 글쓰기 특성 비교. 학습장애연구, 10, 151-165.

고혜정, 박현숙(2005). 이야기문법 자기평가 교수전략이 초등 쓰기장애 학생의 쓰기 표현력 에 미치는 효과. 특수교육학연구, 40, 281-303.

곽금주, 박혜원, 김청택(2001). 한국 웩슬러 아동 지능검사-III (Korean Wechsler Intelligence Scale for Children-III). 서울: 도서출판 특수교육.

김영태, 홍경훈, 김경희, 장혜성, 이주연(2009). 수용·표현어휘력검사(REVT). 서울: 서울장애인종합복지관.

노승림, 김은경(2013). 초등학교 ADHD 학생의 쓰기 특성. 특수교육학연구, 48, 207-228.

안은주, 김정미(2010). 초등학교 2, 4, 6학년 아동의 설명담화 쓰기 비교. 언어청각장애연구, 15, 321-336.

유경, 정은희(2008). 이야기쓰기를 통해 살펴본 학령기 단순언어장애아동의 쓰기 특성. 언어청각장애연구, 13, 63-85.

임종아(2010). 주의력결핍 과잉행동장애 아동의 비유 의미 인식. 언어청각장애연구, 15, 307-320.

조명한(1997). 작업기억과 언어처리의 개인차. 한국심리학회지: 일반, 16, 18-39.

최재인(2005). 전략중심 쓰기 지도 연구: 초등학교 4 학년을 중심으로. 덕성여자대학교 대학원 석사학위논문. 